\title{
Developing the Mobile Learning-based Instructional Media of Excretory Systems in Increasing Students' Concept Mastery at SMAN 1 Delitua
}

\author{
Suci Handayani Nasution \\ Biology Education Postgraduate \\ State University of Medan \\ Medan, Indonesia \\ Sucinst17@gmail.com
}

\author{
Martina Restuati \\ Biology Education Postgraduate \\ State University of Medan \\ Medan, Indonesia
}

\author{
Hasruddin \\ Biology Education Postgraduate \\ State University of Medan \\ Medan, Indonesia
}

\begin{abstract}
The aims of this study were to find out (1) the feasibility of mobile learning-based instructional media; (2) the differences in students' learning outcomes of concept mastery. The subjects were eleventh grade students and biology teachers. At the initial stage, a needs analysis was conducted in which the subjects consisted of 3 biology teachers and 117 eleventh grade students of SMAN 1 Delitua. Small group trials included 9 students. The medium group trials included 1 class totaling 36 students and a large group trials covered 2 classes of eleventh grade students at SMAN 1 Delitua totaling 72 students. For the test phase of the effectiveness of the mobile learning in excretory system, namely the eleventh grade students of SMAN 1 Delitua included the class of XI IPA-1 (Science) and XI IPA-5 (Science). This type of research was a Research and Development (R\&D) with Borg and Gall model. The instruments were the results of teacher and student interviews, assessment questionnaires on mobile learning media and tests of students' concept mastery in excretory system. The results showed that: (1) mobile learningbased instructional media had a very good feasibility; (2) there was a significant difference in students' learning outcomes of the concept mastery taught by mobile learning-based instructional media $(80.00 \pm 3.87)( \pm$ SD $)$ higher than the students' learning outcomes of the concept mastery taught without any mobile learning-based instructional media $(68,47 \pm 5.92)\left(t_{\text {count }}=9,772\right.$; $\mathbf{P}=\mathbf{0 , 0 0 0 )}$ The results implied that mobile learning-based instructional media improve the students concept will become better.
\end{abstract}

Keywords- Mobile Learning-based Instructional Media; Concept Mastery; Learning Independence

\section{INTRODUCTION}

In this era of globalization and information, developing the learning media is also increasingly advanced. The use of Information and Communication Technology (ICT) as a learning medium is a common thing to support learning in schools (Muhson, 2010). In the 2013 curriculum also explained that learning should apply the principle of whoever is a teacher, whoever is a student and anywhere is a class. Therefore, the use of ICT is needed in a series of learning processes, with the development of the use of ICT there are five shifts in the learning process, namely: (1) from training to appearance, (2) from the classroom to, where and at any time, (3) from paper to "online" or channel, (4) from physical facilities to network facilities, and (5) from cycle time to real time (Rosenberg, 2001).

Biological learning has biological material characteristics in the form of facts, concepts, principles, and processes of life symptoms, as well as the ins and outs that affect life including its interaction with the environment and in biology learning, the media needed in learning to help deliver material clearly. One of the media that can be utilized is ICTbased instructional media (Hasruddin, 2009). ICT-based instructional media that can be used by students is mobile learning, which is a learning that is learner (learner) is not silent at one place or learning activity that occurs when learners make use of mobile technology devices (O'Malley, 2003). One of the results of technology that is undergoing development, especially among students is communication technology. In helping to do the assignments given by the teacher, students generally used to search through search engines like Google, Yahoo as a source of information through their gadgets, the same thing was found when the initial survey in SMAN 1 Delitua that $93.16 \%$ of students had used Android-based gadget.

The media commonly used is PowerPoint media, but the teacher said that using PowerPoint media in the class was less able to optimize mastery of students' concepts because it could only be displayed in class and after daily test, midterm test, end of semester test on excretory system, students had not been able to master the concept, namely in the process of urine formation, organs and functions of excretory systems so that cognitive learning outcomes were still low and had not reached class classical completeness, $80 \%$ of students had not reached the minimum completeness criteria. This was because the excretory system required a strong understanding and speed to understand the lessons for each student differently. Some students could understand after learning once. Many students must learn repeatedly in order to understand learning material. Therefore, to help students master the material 
concepts, it is necessary to develop a learning media that fits the needs and ownership of Android gadgets by students.

Based on the needs analysis, the initial survey and the problems described previously, it is necessary to develop a mobile and representative learning media and can be repeated anywhere and anytime when students need it, which in turn can optimize the students' concept mastery in excretory system material. It is expected that developing the mobile learning can provide different experiences in the learning process of students because mobile learning can be used independently by students.

\section{RESEARCH METHOD}

This study was carried out at SMAN 1 Delitua, Deli Serdang District, North Sumatra Province from December 2017 to May 2018. The research subjects were eleventh (XI) grade students and biology teachers. At the initial stage, a needs analysis was conducted in which the subjects consisted of 3 biology teachers and 117 eleventh grade students of SMAN 1 Delitua. Small group trials cover 9 students. The medium group trial includes 1 class totaling 36 students and a large group trial covering 2 eleventh classes at SMAN 1 Delitua was 72 students. For the test phase of the effectiveness of the mobile learning excretory system, namely the eleventh grade students of SMAN 1 Delitua include the XI-IPA 1 (Science) and XI-IPA 5 (Science). This type of study was Research and Development ( R \& D) with the model of Borg and Gall design which consisted of 10 systematic steps, namely; (1) observation and collection of information; (2) planning; (3) development; (4) initial field testing; (5) first revisions; (6) main field trials; (7) second revisions; (8) test of operational fields; (9) third revisions; and (10) product implementation.

\section{RESULTS}

Developing the mobile learning-based instructional media in excretory system for students of XI-IPA at SMAN 1 Delitua in this study consisted of validations: (1) material experts, (2) media design experts, and (3) technology experts. Aspects of assessment of material experts include: (1) material indepth, (2) material Submission System, (3) presentation, (4) supporting learning, (5) material Accuracy, (6) material update, and (7) language (communicative, straightforward, interactive) obtained by very good categories, on aspects: material (95.95\%), learning media design (86.89\%), and learning media technology (92.92\%). Furthermore, developing the mobile learning-based learning media in excretory system was very feasible to use for eleventh grade students.

Based on the results of the t-test it was found that there were significant differences in the learning outcomes of students' concept mastery in excretory system taught by mobile learning-based instructional media with no mobile learningbased instructional media $\left(\mathrm{t}_{\text {count }}=9.772 ; \mathrm{P}=0,000\right)$. In addition, the learning outcomes of students' concept mastery in excretory system taught by mobile learning-based instructional media $(80.00 \pm 3.87)( \pm \mathrm{SD})$ were higher than the learning outcomes of students' concept mastery taught without mobile learning-based instructional media $(68,47 \pm 5.92)$.

\section{DISCUSSION}

Developing the mobile learning-based learning media in excretory system for eleventh grade students of SMAN 1 Delitua in this study was obtained with a very good category, then developing the mobile learning-based learning media in excretory system was very feasible to use for eleventh grade students. Effective Mobile Learning media is used as a learning media because the students in the $21^{\text {st }}$ century include the generation of digital natives. This is in line with students' responses based on questionnaires whose responses are very positive towards mobile learning media because mobile learning-based learning media is a media that utilizes technology and mobile devices, especially on smartphones or tablets that have operating systems such as the Android operating system, and iOS.

Through mobile learning, students of XI-Science at SMAN 1 Delitua can access learning content anywhere and anytime, without having to visit a certain place at a certain time. With the concept of learning mobile will bring the benefits of the availability of teaching materials that can be accessed by students at any time and visualization of material that is interesting for students. So that with mobile learning, the efficiency and effectiveness of the process and learning outcomes of eleventh grade students at SMAN 1 Delitua can increase and be able to penetrate the tendency of students to want to learn better in the future. As the results of the research by Siraj (2004) concluded that mobile learning is learning that provides easier and faster communication space.

This is also supported by the results of Iskandar (2004) who concluded that the use of applications in mobile phone is growing very rapidly, but the use of these applications to be used by students still needs to be improved, the view of using mobile phones to be used as instructional media includes increasing numbers that mobile phone users have opened up opportunities for the development of instructional media with the concept of mobile learning so that learning can be done anywhere and anytime without being bound by space and time. Yuen, et al. (2011) also concluded that the rapid advances in technology have touched various groups including students. Because of these changes, the characteristics of students continue to grow, such as in terms of skills, and areas of expertise and knowledge that are valuable in society.

The results of Danang's study (2015) concluded that mobile learning media had a significant effect in improving critical thinking skills and student learning independence and the results of media experts and material experts' assessment showed that mobile learning media with the theme of the immune system was very feasible to use as a learning medium of eleventh grade students. Yuniati's (2015) research also concluded that android smartphones can be used as alternative media or teaching materials to improve students' understanding of certain materials, android teaching systems 
(involving text, images, videos) can present material more interesting, not monotonous, facilitate delivery and students can learn material independently.

Jeno (2016) study also concluded that mobile learning provides students no need to be present in the class just to collect assignments, enough tasks are sent through an application on a mobile phone that indirectly will improve the quality of the learning process itself. Murhaini (2016) also found that using or implementing mobile learning can form a learning paradigm that can be done anywhere and anytime. Where the concept of learning mobile learning brings the benefits of the availability of teaching materials that can be accessed at any time and the visualization of interesting material.

Thus, mobile learning is a learning model that utilizes information and communication technology. Where the concept of mobile learning brings the benefits of the availability of teaching materials that can be accessed at any time and the visualization of material that is of interest to eleventh grade students at SMAN 1 Delitua. Through mobile learning, the learning process can run all the time (long life learning), so students can be more active in the learning process, saving time because when applied in the learning process. With mobile learning, the efficiency and effectiveness of the process and learning outcomes of students can increase and be able to increase the tendency of students to want to learn better in the future as Edgar Dale (1969) stated that the acquisition of sensory learning results range $75 \%$, hearing senses $13 \%$ and through other senses around $12 \%$. Based on the cone of experience presented by Edgar Dale, the mobile learning media developed has facilitated the experience of students as much as $50 \%$ (visual, auditory) which is up to the stage of seeing and hearing learning from teachers assisted with mobile learning media.

\section{CONCLUSION}

Developing the mobile learning-based instructional media of excretory system for eleventh grade students at SMAN 1 Delitua 1 in this study was obtained with a very good category, on aspects: core material $(95.95 \%)$, learning media design $(86.89 \%)$, and learning media technology (92.92\%). Furthermore, developing the mobile learning-based instructional media of excretory system was very feasible to apply for eleventh grade students besides the learning outcomes of students' concept mastery of excretory system taught by using mobile learning-based instructional media $(80.00 \pm 3.87)( \pm$ SD $)$ higher than the learning outcomes of students' concept mastery taught without mobile learningbased instructional media $(68.47 \pm 5.92)(\mathrm{t}$-count $=9.772 ; \mathrm{P}=$ 0,000).

\section{ACKNOWLEDGMENT}

Thank you for my thesis supervisors, Mrs. Dr. Martina Restuati, M.Si. and Mr. Dr. Hasruddin, M.Pd., who helped me a lot in completing this article and SMAN 1 Delitua that helped me a lot in collecting data for the completion of this article.

\section{REFERENCES}

[1] Danang, G. 2015. Pengembangan Mobile Learning Berbasis Android Materi Sistem Imun untuk Meningkatkan Kemampuan Berpikir Kritis dan Kemandirian Belajar Siswa Kelas XI SMA. Tesis. Universitas Yogyakarta.

[2] Hasruddin. 2009. Peran Multimedia Dalam Pembelajaran Biologi. Jurnal Tabularasa PPs Unimed. 6(2): 149-150.

[3] Iskandar, D., dan Soesianto, I. F. 2010. Pengembangan Aplikasi Berbasis Teknologi Mobile Untuk Pembelajaran. Doctoral Dissertation: Universitas Gadjah Mada.

[4] Jeno,M. 2016. The Effect of a Mobile Application Tool on Biology Students Motivation and Achievement in Species Identification : A Self Determination Theory Perspective. Elsevier. 107(1): 2-5

[5] Muhson. 2010. Pengembangan Media Pembelajaran Berbasis Teknologi Informasi. Jurnal Pendidikan Akutansi Indonesia, 3(2): 1-2.

[6] Murhaini, S. 2016. Menjadi Guru Professional Berbasis Teknologi Informasi dan Komunikasi. Yogyakarta: LaksBang PRESSindo.

[7] O'Malley. 2003. Guidelines For Learning/Teaching/Tutoring in a Mobile Environtment. United State of America: Longman.

[8] Rosenberg, M. J. 2001. E-Learning: Strategies For Delivering Knowledge In The Digital Age. USA: McGraw-Hill Companies.

[9] Siraj, S., dan Saleh, M. 2004. Pembelajaran Mobile dalam Kurikulum Masa Depan. Masalah pendidikan, 27(1): 128142.

[10] Yuen, Steve Chi-Yin et al. 2011. Augmented Reality: An Overview and Five Directions for AR in Education. Journal of Educational Technology Development and Exchange, 4(1): 132.

[11] Yuniati, F., Dewi, P., Susanti, R. 2015. Pengembangan Virtual Laboratory sebagai Media Pembelajaran Berbasis Komputer pada Materi Pembiakan Virus. Unnes Journal of Biology Education, 1(1): 27-35. 